\title{
Farmers' knowledge and perception regarding the importance of cover crops in the Northern Agricultural Zone of Delta State, Nigeria
}

\author{
Ajieh, P.C ${ }^{*}$ and Uzokwe, U.N* \\ *Department of Agricultural Economics \& Extension Delta State University, Asaba Campus, Asaba, Nigeria
}

\begin{abstract}
The study examined farmers' knowledge and perception regarding the importance of cover crops in the northern agricultural zone of Delta State, Nigeria. Eighty crop farmers that were randomly selected served as respondents of the study. Data were collected through the use of structured interview schedule. Descriptive statistics such as frequency count, mean scores, and percentage were used to summarize data. Farmers' knowledge of cover crops was determined through a knowledge test, while Likert scaling was used in determining perception on the importance of cover crops and constraints to the utilization of cover crops. Results reveal that majority of the farmers operate on a small-scale with farm size ranging between 1 and 3 hectares. About 75 percent of the farmers had formal education. Majority of the farmers plant cover crops primarily for consumption and income generation not as a soil conservation measure. Popular cover crops planted include melon, beans and sweet potato. Farmers had a low knowledge on cover crops, however, majority of the farmers "agreed" with 13 of the 15 importance of cover crops investigated by the study. This suggests that they understand the rationale for the use of cover crops. Important constraints to the use of cover crops identified by the study include: attracts and harbor pests $(M=2.66)$, difficult to manage $(M=2.75)$, increase cost of production $(M=2.93)$, adds excessive residue to the soil $(M=2.66)$, and competes with food crops for space, light and nutrients $(M=3.44)$. Based on the findings of this study, it concludes that crop farmers in northern agricultural zone presently do not exploit the full benefits of cover crops because of their limited use of cover crops. The study recommends that the farmers should increase their level of cover crops utilization by planting different cover crops species.
\end{abstract}

Key words: Farmers, Cover crops, knowledge, Perception, Importance

\section{Introduction}

Crop production is one of the destructive environmental activities that results in the depletion of soil nutrient resources. This is usually aggravated by deleterious cultural practices such as mono cropping, continuous cropping, over tillage and over cropping (Lutchenberg et al, 1994). The resultant effect of these cultural practices is reduction in the productivity of the soil. Different soil management methods have been evolved to enhance the productive potential of soils. One of the notable methods is the use of cover crops.

According to Lu et al, (2000), cover crops are annual, biennial and perennial plants grown to improve a number of soil conditions associated with sustainable crop production. They can either be planted between cash crops cycles or intercropped with cash crops. Cover crops include many types of crop that may or may not be harvested. They are mainly grown for soil fertility management.

According to Dabney, Delgado and Reeves (2001), the main functions of cover crops in sustainable crop production include the following

- increase soil organic matter, stimulate soil biological activity or improve soil physical characteristics. When cover crops are incorporated as green manures, they break down into various types of organic matter. Mature and fibrous crop materials are characterized by relatively high carbon: nitrogen $(\mathrm{C}: \mathrm{N})$ ratio, and generally consist of complex lignin compounds that do not readily decompose. This slow decomposition generates long-lived or stable organic matter referred to as "humus" which improves soil physical characteristics;

- to protect soil from wind and water erosion. As the name implies, cover crops are commonly used to cover and protect the soil surface from erosion. The top growth covers the soil while the roots bind and stabilize the soil particles;

- to recycle valuable nutrients that are present but not readily available to plants. Deep rooted cover crops have the ability to extract nutrients from the deep soil horizons and bring them to the surface, near the root zones of subsequent cash crops. Some cover crops are also known for their ability to extract nutrients that are not readily available to other plants; 
- to catch or conserve nutrients that may be lost through leaching. "Catch" crops are used to catch and retain nutrients that may otherwise be leached out of the cropping system. Catch crops planted after early potatoes, cereals or vegetable help to capture available nutrients that were not taken up by the crops;

- to interrupt pest and disease cycles and/or suppress weeds; some cover crops help to interrupt life cycle of many fungal, bacterial, insect or nematode pests. Several cover crops are also considered as "smother" crops because they are used to suppress weeds. Such crops compete with the weeds for water, sunlight, space, rooting zone and nutrients.

Different types of leguminous and non-leguminous cover crops have been used to improve soil productivity. Notable leguminous crops include beans, melon, cowpea, peanut and soybean. They have the ability to 'fix' atmospheric nitrogen due to the symbiotic relationship with certain bacteria known as rhizobia (Giller and Cadish, 1995).Non-leguminous cover crops that have been inter planted with other crops to either suppress weeds, reduce nutrient leaching or inhibit or slow growth of other nearby plants by releasing natural toxins or "allelo chemicals" include rye, sorghum, sudan grass, wheat, millet and oil seed radish (Potter et. al; 1998; Singh et al; 2003)

Effective utilization of cover crops depends to a large extent on a proper understanding of the role they play in sustainable crop production. It is in the light of this fact, that this study was conceived to examine the knowledge and perception of farmers regarding cover crops and their importance in enhancing soil productivity. The specific objectives of the study were to:

- describe the socio-economic characteristics of respondents;

- ascertain respondents' knowledge regarding cover crops;

- determine respondents' perception regarding the importance of cover crops; and

- ascertain the constraints the utilization of cover crops

\section{Methodology}

The study was carried out in the Northern Agricultural Zone of Delta State, Nigeria. A multistage sampling technique was used in selecting respondents for the study. In the first stage, four extension blocks (Local Government Areas) were randomly selected out of the nine extension blocks in the agricultural zone. In the second stage, two extension cells were randomly selected from each of the selected extension blocks. This gave a total of eight extension cells. In the third stage, 10 Crop farmers were randomly selected from each of the eight selected extension cells. This gave a total of 80 farmers that served as respondents of the study.

Data were collected from the respondents of the study through the use of a validated structured interview schedule. To obtain a quantitative measure of respondents' knowledge of cover crops, ten questions were developed regarding the meaning, types and cover crop mixtures. A maximum of 1 point was awarded to a correct answer and 0 point was awarded for a wrong answer. This implied that the knowledge score of respondents could vary from zero to ten, where zero indicates no knowledge and 10 indicates highest knowledge level about cover crops. Based on respondents' knowledge score, they were categorized into three as follows: (a) low level (score of 0-4); (b) Medium level (score 5-8); and (c) high level (score of 9-10).

Likert scaling and mean scores were used to determine respondents' perceptions regarding the importance of cover crops and constraints to the utilization of cover crops. Likert scaling for respondents' perception of the importance of cover crops was based on a four-point rating scale of Strongly disagree (SD); Disagree (D); Agree (A); and Strongly agree (SA); with assigned values of 1,2, 3 and 4 respectively. Also, a four- point Likert scaling of Not important $=1$, Barely important $=2$, important $=3$, and very important $=4$ was used to ascertain respondents' perception on constraints to utilization of cover crops. The mean of the response values which is 2.5 was used as cut-off point. Thus, scores of 2.5 and above was regarded as "agreed" or "important", while score of below 2.5 was regarded as "disagreed" or "unimportant". Descriptive statistics such as frequency count, percentage and mean were used to summarize data.

Table 1: Extension Blocks and Cells used for the study

\begin{tabular}{cl}
\hline Extension blocks & Extension cells \\
\hline Ika North East & Ute-erumu, Umunede \\
& \\
Aniocha North & Onicha-Ugbo, Obomkpa \\
Ukwuani & Umuaja, Amai \\
Oshimili South & Oko-amakom, Anwai \\
\hline
\end{tabular}




\section{Socio-economic characteristics of respondents}

\section{Results And Discussion}

Entries in Table 2 reveal that 60 percent of the respondents are males while 40 percent are females. This indicates that men dominate crop production activity in the area. Data on respondents' age show that 55 percent of them were within the age bracket of 21 and 40 years while 45 percent fell within the age of 41 and 60 years. The mean age of the respondents was 40 years which suggests that majority of them are in their middle age and therefore are still active and productive.

Information in Table 2 further show that 75 percent of the respondents had various forms of formal education ranging from primary to post secondary education. Results on farming experience of respondents reveal that 66 percent of them had between 11 and 20 years experience while 34 percent of them had between 1 and 10 years experience. The mean farming experience of the respondents was 13 years. These findings indicate that majority of the respondents had sufficient experience in crop farming. Data on respondents' farm size showed that 56 percent of them had farm size of between 1 and 3 hectares while the mean farm size of the respondents was 3 hectares. This indicates that majority of the crop farmers in the respondents operate as small scale farmers. According to Akatugba-Ogisi (1994), farmers with farm size of 3 hectares and below are small scale farmers. This category of farmers is more likely to use cover crops since it is a less expensive method of soil amendment.

Data on the types of cover crops planted indicate that 85 percent of the respondents plant melon while 74 percent plant beans. Another 78 percent of the respondents plant sweet potato. Information on cover crops mixtures reveals that 93 percent of the respondents plant melon and sweet potato in combination. Respondents revealed that they plant cover crops not only for the purpose of weed control and soil nutrients improvement but primarily for consumption and income generation. This may be the reason for the wide use of leguminous cover crops which are usually harvested for sale and consumption by the farmers.

Table 2: Distribution of respondents according to their socio-economic characteristics

\begin{tabular}{|c|c|c|c|}
\hline Socio-economic characteristics & Frequency & Percentage & Mean \\
\hline \multicolumn{4}{|l|}{ Age (in years) } \\
\hline $12-30$ & 24 & 30 & \multirow{3}{*}{40} \\
\hline $31-40$ & 20 & 25 & \\
\hline $51-60$ & 23 & 29 & \\
\hline \multicolumn{4}{|l|}{ Sex } \\
\hline \multicolumn{4}{|l|}{ Marital status } \\
\hline Married & 56 & 70 & \\
\hline Single & 24 & 30 & \\
\hline Post Secondary education & 6 & 8 & \\
\hline \multicolumn{4}{|l|}{ Farming experience (years) } \\
\hline $1-5$ & 10 & 13 & \multirow{4}{*}{13} \\
\hline $6-10$ & 17 & 21 & \\
\hline $11-15$ & 22 & 27 & \\
\hline $16-20$ & 31 & 39 & \\
\hline \multicolumn{4}{|l|}{ Farm size (Hectares) } \\
\hline $1-1.5$ & 15 & 19 & \\
\hline $1.6-3.0$ & 30 & 37 & \\
\hline $3.1-5.0$ & 31 & 39 & \\
\hline
\end{tabular}

- Multiple responses recorded 


\section{Respondents' knowledge regarding cover crops}

Data in Table 3 show the knowledge level of respondents regarding cover crops. According to the knowledge assessment score, respondents were categorized into three levels, namely, low, medium and high. Results reveal that majority of the respondents (61 percent) had low knowledge while 10 percent of them had high knowledge. The remaining 29 percent of the respondents had medium knowledge. This suggests that majority of the respondents in this study had low knowledge regarding cover crops.

Table 3: Distribution of respondents according to their knowledge of cover crops

\begin{tabular}{|l|c|c|c|}
\hline Knowledge level & Knowledge score & Frequency & Percentage \\
\hline Low & $0-4$ & 49 & 61 \\
\hline Medium & $5-8$ & 23 & 29 \\
\hline High & $9-10$ & 8 & 10 \\
\hline
\end{tabular}

\section{Respondents' Perception of the importance of cover crops}

Entries in Table 4 show the mean scores and standard deviations of respondents' perception of the importance of cover crops. Results reveal that respondents "agreed" with 13 out of the 15 importance of cover crops listed in this study. The only two importance of cover crops which respondents disagreed with are: Cover crops serves as vegetables for human consumption $(M=2.28)$ and cover crops reduces cost of fertilizer $(M=2.18)$. These findings are understandable since the types of cover crops grown by farmers in the study area are not commonly consumed as vegetables. Also, it was found that there was a generally low utilization of fertilizers among the farmers and therefore they could not determine the cost reduction in fertilizer associated with the use of cover crops.

The importance of cover crops which respondents agreed with include: cover crops increase yield $(M=$ $2.99)$; cover crops enhance soil fertility $(M=3.24)$; cover crops suppress weeds $(M=3.05)$; cover crops improve water holding capacity $(M=2.84)$; cover crops reduce erosion $(M=3.09)$; cover crops increase soil nitrogen ( $M=3.13)$; cover crops reduce water evaporation $(M=3.26)$; cover crops increase soil organic matter $(\mathrm{M}=3.46)$; cover crops serve as a source of additional income $(M=3.78)$; cover crops reduce cost of weeding $(M=2.59)$; cover crops suppress growth of other crops $(M=2.28)$; and cover crops compete for space, light and water with other crops $(M=2.05)$.

The above importance of cover crops has been well documented in literature and usually explains the rationale for the utilization of cover crops in crop production. Farmers in the area of study, however, may not exploit the full benefits of cover crops due to their limited use of cover crops species. This study revealed that farmers plant only leguminous cover crops which are usually harvested by them for consumption and sale to generate income. Leguminous cover crops essentially have the advantage of nitrogen fixation, while nonleguminous cover crops are known to have the advantage of pest control, reduction of soil compaction, addition of organic humus and control of soil erosion and leaching. Some non-leguminous cover crops also have allelopathic properties that can inhibit the germination of weeds that have small seeds.

Table 4: Mean scores and standard deviations of respondents' perception of the importance of cover crops $(\mathbf{n}=\mathbf{8 0})$

\begin{tabular}{|c|c|c|c|c|}
\hline $\mathrm{S} / \mathrm{N}$ & Importance of cover crops & $\begin{array}{l}\text { Mean } \\
\text { score }\end{array}$ & $\begin{array}{l}\text { Standard } \\
\text { deviation }\end{array}$ & Remarks \\
\hline 1 & Increase crop yield & 2.99 & 0.76 & Agreed \\
\hline 2 & Enhance soil fertility & 3.24 & 0.60 & Agreed \\
\hline 3 & Suppress weeds & 3.05 & 0.78 & Agreed \\
\hline 4 & Improve soil water holding capacity & 2.84 & 0.97 & Agreed \\
\hline 5 & Reduce soil erosion & 3.09 & 0.51 & Agreed \\
\hline 6 & Serve as vegetable for human consumption & 2.28 & 0.79 & Disagreed \\
\hline 7 & Increase soil nitrogen & 3.13 & 0.65 & Agreed \\
\hline 8 & Reduce soil water evaporation & 3.06 & 0.69 & Agreed \\
\hline 9 & Increase soil organic matter & 3.46 & 0.55 & Agreed \\
\hline 10 & Serve as additional income & 3.78 & 0.56 & Agreed \\
\hline 11 & Easy to manage & 2.61 & 0.76 & Agreed \\
\hline 12 & Reduce cost of weeding & 2.59 & 0.67 & Agreed \\
\hline 13 & Reduce cost of fertilizer & 2.18 & 0.69 & Disagreed \\
\hline 14 & * Suppress growth of other crops & 2.28 & 0.79 & Disagreed \\
\hline 15 & * Compete for space, light and water with crops & 2.05 & 1.09 & Disagreed \\
\hline & Cut-off point & 2.50 & & \\
\hline
\end{tabular}

Key: $*$ Negative statement 


\section{Constraints associated with the use of cover crops}

Entries in table 5 show that the mean scores and standard deviations of constraints associated with the use of cover crops. Results reveal that five out of the 15 possible constraints investigated in this study were considered to be serious by the respondents. They include: attracts and harbour pest $(\mathrm{M}=2.66)$; difficult to manage ( $M=2.75)$; increase cost of crop production $(M=2.93)$; add excessive residue to the soil $(M=2.66)$; and compete with food crops for space, light and nutrients $(M=3.14)$.

The use of cover crops is not without some potential problems. The serious constraints identified in this study have been documented. They go a long way in determining the amount of benefits a farmer can get from the use of cover crops. Many annual cover crops prove very difficult to manage. Most often, they produce viable seeds and when mowed into the soil, these seeds usually grow to become weed. Some cover crops also attract, stimulate or harbour pests that can negatively impact on food or cash crops. Large amounts of cover crop residues can cause significant problems during seeding of the next crop. Wallace and Scott (2008) noted that precision seeders are particularly sensitive to seed bed conditions with excessive crop residues.

Table 5: Mean scores and standard deviations of constraints associated with use of cover crops

\begin{tabular}{|c|c|c|c|}
\hline $\mathrm{S} / \mathrm{N}$ & Constraints & Mean score & $\begin{array}{l}\text { Standard } \\
\text { deviation }\end{array}$ \\
\hline 1 & Difficult to manage & $2.75^{*}$ & 0.75 \\
\hline 2 & Increase cost of labour & 2.09 & 0.69 \\
\hline 3 & Occupy available land space & 1.54 & 0.76 \\
\hline 4 & Increase cost of crop production & $2.69 *$ & 0.79 \\
\hline 5 & Reduce crop yield & 1.86 & 0.51 \\
\hline 6 & Reduce soil moisture & 1.96 & 0.54 \\
\hline 7 & Attract and harbour pests & $2.93 *$ & 0.65 \\
\hline 8 & Add excessive nitrogen to the soil & 2.31 & 0.56 \\
\hline 9 & Make weeding difficult & 1.92 & 0.50 \\
\hline 10 & Reduce available soil nutrients & 2.25 & 0.45 \\
\hline 11 & Add excessive residue to the soil & $2.89 *$ & 0.60 \\
\hline 12 & Tie up nitrogen during composition & 1.85 & 0.50 \\
\hline 13 & Require additional time and expense & 1.76 & 0.48 \\
\hline 14 & Compete with food crop for space and nutrient & $3.14 *$ & 1.09 \\
\hline \multirow[t]{2}{*}{15} & Reduces available soil water & 1.86 & 0.51 \\
\hline & Cut-off point & 2.50 & \\
\hline
\end{tabular}

Key: $*=$ Serious constraints

\section{References}

[1]. Akatugba-Ogisi (1994) Multiple objectives and small farmers production behaviour in Delta and Edo States of Nigeria: Application of goal programming. Ph.D Thesis, Department of Agricultural Economics and Management, University of Reading, UK

[2]. Dabney, S.M., Delgado, J.A. and Reeves, D.W. (2001) Using winter cover crops to improve soil quality and water quality. Communications in Soil Science and Plant Analysis

[3]. Giller, K.E. and Cadish, G. (1995) Future benefits from biological nitrogen fixation: An ecological approach to agriculture. Plant and Soil Historical Archive

[4]. Lichenberg, E.J.C., Decker, A.M. and Clark, A.J. (1994) A profitability analysis of legume cover crops in the Mid Atlantic Region. Journal of soil and water conservation

[5]. Lu, Y.C., Watlains, K.B. and Teasdale, J.R. (2000) Cover crops in sustainable Food Production, Food Receivers International

[6]. Potter, M.J., Davies, K., and Ranthjen, A.J. (1998) Suppressive impact of glycosinolate in Brassica vegetative tissues on root lesson nematode pratelendus neglectus. Journal of Chemical Ecology, 24: 67 - 80

[7]. Singh, H.P., Batish, D.R. and Kholi, R.K. (2003) Allelopathic interactions and allelochemicals: New Possibilities for sustainable weed management. Critical Reviews in Plant Sciences, 22: 239 - 311.

[8]. Wallace, J. and Scott, J. (2008) Under cover - a guide to using cover crops in the Maritimes, $2^{\text {nd }}$ Edition, Nova Scotia Organic Growers Association and Atlantic Canadian Organic Regional Network. 71 pages 